\title{
Bioremediation of Crude Oil-Contaminated Soil using Compost as Bio-Stimulant
}

\author{
*EDEKOR, PE; UWADIAE, SE \\ Department of Chemical Engineering, University of Benin, PMB 1154, Benin City, Nigeria \\ *Corresponding Author Email: patrickedekor724@gmail.com
}

\begin{abstract}
This study was conducted to investigate the usability of compost as a stimulant for the remediation of crude oil-contaminated soil. $2 \mathrm{~kg}$ of porous sandy soil was measured into six different equal-sized cells and contaminated with $250 \mathrm{ml}$ of sample crude oil. Masses of solid waste comprising of compost and sawdust were measured in varying amounts of $900 \mathrm{~g}, 750 \mathrm{~g}, 600 \mathrm{~g}, 450 \mathrm{~g}, 300 \mathrm{~g}$, and a control sample that had no compost and sawdust. The set-up was left to stand for eight weeks and the residual hydrocarbon content (RHC), pH, and total microbial count (TMC) of these samples were monitored and recorded. The percentage of hydrocarbon degradation that occurred in the treatment cells were; $33.11,32.2,31.2,29.46$ and 28.05 respectively, for the individual cells in the order above, while the control had a degradation rate of $(0.44 \%)$ of the total hydrocarbon content after 8 weeks. $\mathrm{pH}$ values varied slightly within the ranges of 6.5-7.5. The TMC average values were $21,188,17,125,15,000,14,250$, 13,125 and 0.1 , with the highest count occurring in the sample having $900 \mathrm{~g}$ of solid waste; followed by the other samples having lesser quantities of solid waste with the least value in the control. The resultant descent in TMC across each of the samples was due to the distribution of waste material in the samples, and the $\mathrm{pH}$ of the resulting mixtures remained at optimum, thereby favouring microbial growth across the samples.
\end{abstract}

\section{DOI:https://dx.doi.org/10.4314/jasem.v25i11.2}

Copyright: Copyright ( 92021 Edekor and Uwadiae. This is an open access article distributed under the Creative Commons Attribution License (CCL), which permits unrestricted use, distribution, and reproduction in any medium, provided the original work is properly cited.

Dates: Received: 22 August 2021; Revised: 17 September 2021; Accepted: 06 October 2021

Keywords: Crude oil, residual hydrocarbon content, total microbial count, Remediation, Bio-stimulant

Petroleum-based products are the major sources of energy for industry and daily life and as the world's dependence on crude oil and its derivatives increases, so does the level of exploration. This has created the conditions for the potential distribution of large amounts of toxins associated with crude oil into the environment (Obahiagbon et al., 2014). Decontamination of sites by biological means has received significant attention.

Specifically, bioremediation has been identified as a sustainable and suitable option for the decontamination of crude oil-polluted soil, it has a relatively low cost of operation, low technology requirements, it is easily implanted and the pollutants are degraded into less toxic forms in a relatively short time (Erdogan and Karaca 2011; Otokunefor and Obiukwu, 2010). It involves the use of microorganisms with the capacity to degrade these hydrocarbons and mineralize them into simpler and less toxic forms such as $\mathrm{CO}_{2}$ and $\mathrm{H}_{2} \mathrm{O}$ (Amenaghawon et al., 2013). Bioremediation, as a cleanup method, is typically implemented through either of three strategies namely; natural attenuation, biostimulation, or bioaugmentation ( $\mathrm{Yu}$ et al., 2005). Natural attenuation refers to the combination of natural processes that occur without human involvement, to decrease or "attenuate" contaminant concentrations and toxicity in land or wastewater, and thereby reduce the hazards posed by the contaminants. The process of externally stimulating microbial growth and activity for the remediation of contaminants is referred to as biostimulation. The low population of indigenous microorganisms is one of the major limitations of bioremediation through natural attenuation.

In some instances the indigenous microorganisms do not even possess the natural metabolic activity necessary to degrade the hydrocarbon pollutants hence the need for a specialized consortium of microbes which is added to the remediation medium exogenously (El Fantroussi and Agathos, 2005). Since biological processes are often highly specific, important site factors required for successful bioremediation like; the presence of metabolically capable microbial populations, suitable environmental growth conditions, and appropriate levels of nutrient (organic waste or compost), must thus be maintained (Vidali., 2001).

In this study, compost was used to stimulate the growth and multiplication of oil-eating microbes (bacteria and fungi) for the remediation of soil polluted with crude oil. 


\section{MATERIALS AND METHODS}

Sample Collection and Preparation:The soil sample was collected from the surrounding of the department of Chemical Engineering, University of Benin. Crude oil was obtained from NPDC flow station, Ologbo, Edo state. The collected soil sample was air-dried and mechanically homogenized by removing pebbles, plastics and metals, and screened using a $2.8 \mathrm{~mm}$ mesh size sieve. Moisture content and $\mathrm{pH}$ of the test samples were determined to know their initial conditions. The solid waste (compost) consisted of poultry droppings, which was obtained from the faculty of agriculture, University of Benin.

$2 \mathrm{~kg}$ of soil sample was measured into 6 different cells and contaminated with $250 \mathrm{ml}$ of crude oil each, and mixed thoroughly using a hand trowel. Varying masses of solid waste (poultry droppings and sawdust) which served as amendments/bio-stimulants were weighed in masses of $0.3 \mathrm{~kg}, 0.45 \mathrm{~kg}, 0.6 \mathrm{~kg}, 0.75 \mathrm{~kg}$ and $0.9 \mathrm{~kg}$ respectively, and were added to each of the five cells which served as the test samples. One cell was labelled the control sample and contained only crude oil and $2 \mathrm{~kg}$ soil.

The 6 cells (i.e. the test samples and the control sample) were allowed to stand for one week, to allow for the growth and adaptation of indigenous microbes. Finally, bioremediation indication parameters; $\mathrm{pH}$, Residual hydrocarbon content (RHC), and Total microbial count (TMC) were monitored for a period of 8 weeks.

Determination of $\mathrm{pH}$ : The $\mathrm{pH}$ of the samples was determined using the procedure reported by (Satsangee et al., 1990). 20g of soil sample was webighed into $100 \mathrm{ml}$ beaker, mixed with $20 \mathrm{ml}$ of distilled water and stirred thoroughly. The mixture was allowed to stand for 30 minutes and then the $\mathrm{pH}$ value was determined using an electric $\mathrm{pH}$ metre (Phs 25 Techmel, USA). The electrode system of the $\mathrm{pH}$ meter was first calibrated using a standard buffer solution after which the sample was thoroughly mixed using a stirrer and its $\mathrm{pH}$ measured and recorded.

Determination of Residual Hydrocarbon Content (RHC):The residual hydrocarbon content of the soil was determined using a method described by (Osuji and Nwoye 2007). A mixture of $5 \mathrm{~g}$ of contaminated soil and $50 \mathrm{ml}$ of $\mathrm{n}$-hexane was vigorously shaken for 20 minutes. The mixture was then left to stand for 20 minutes, after which it was filtered with Whatmann filter paper (no 2). The RHC was calculated after reading the absorbance of the extract from the spectrophotometer at a wavelength of $425 \mathrm{~nm}$.
Determination of Total Microbial Count (TMC):Dilution of the soil sample was prepared by washing soil with distilled water and then diluting using the diluent already prepared (obtain $10^{-1}, 10^{-3}$ and $10^{-6}$ dilutions) using the procedure reported by (Bassiri, 2011). The Colony counting chamber was assembled by applying the cover glass. Few drops of Methylene blue solution were added to the water sample and the dilution. With a standard loop, a loopfull of water sample (including the various dilutions) was placed on the ruled area of the counting chamber and then the chamber was allowed to stand for $5 \mathrm{mins}$. It was then examined under a microscope using an $\mathrm{mm}$ lens (x 16 objective lens) to count the bacteria in 50100 square selected at random so that the total number of bacteria is about 500. For each sample, a triplicate was obtained, counted and divided by the number of counts, then by the number of squares and the result multiplied by the dilution factor and a constant $\mathrm{k}$. This gave the number of organisms in a millilitre of the given water sample.

\section{RESULTS AND DISCUSSION}

Variation of $\mathrm{pH}$ with time:The result obtained for the $\mathrm{pH}$ of samples of varying masses over a period of 8 weeks is given below:

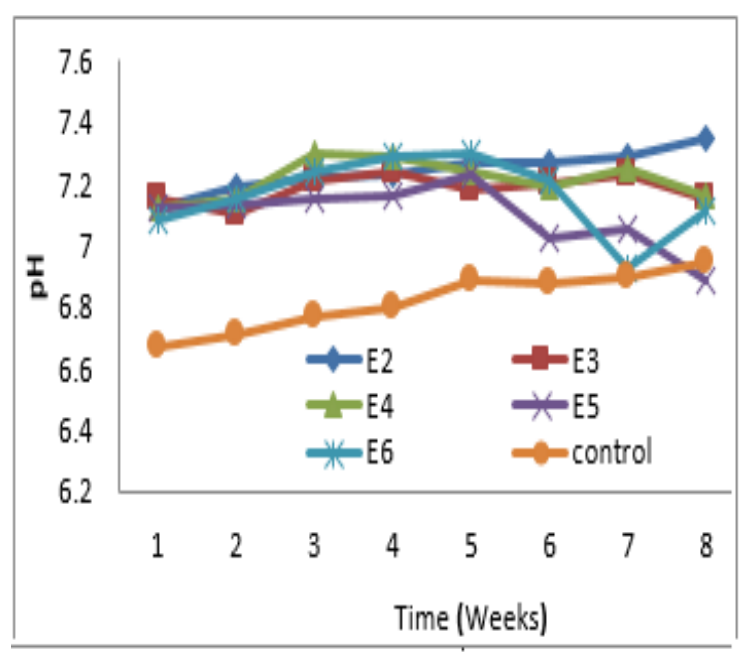

Fig 1: Variation of $\mathrm{pH}$ with time

It can be seen from the figure above that during the first week, all the samples had initial $\mathrm{pH}$ levels of 6.57.3. Subsequently, in the second week, there was a negligible increase in the $\mathrm{pH}$ of all the samples; this was as a result of the addition of organic material (compost) which increases the value of $\mathrm{pH}$ due to their slightly alkaline nature. Over time, there was a steady increase in $\mathrm{pH}$, which may be due to the increase in microbial population and activities. In the $5^{\text {th }}$ and $6^{\text {th }}$ weeks, some samples began to experience lower $\mathrm{pH}$ levels, but these $\mathrm{pH}$ levels still provided optimum 
conditions for biodegradation to occur, as they still fell within the optimum range of 6.5-7.5.

It can also be seen that the control (soil + crude oil) had the lowest value in $\mathrm{pH}$ in comparison with the samples containing solid waste (compost) throughout the eight weeks period, which was indicative of the fact that there was no addition of compost, hence, little or no microbial activity. Solid waste (compost) has helped in the remediation of the soil by increasing the $\mathrm{pH}$ to favour microbial activities (Golodyaevet al., 2009).

Residual Hydrocarbon Content:Figure 2 shows the residual hydrocarbon content throughout 8 weeks. Bioremediation of petroleum and hydrocarbons in the soil is a complex process where quantitative and qualitative aspects depend on the nature and amount of hydrocarbon(s) present. It can be seen from Figure 2 that the RHC decreased with time for the various samples, in comparison with the control sample which had a negligible decrease in its RHC. This may have been because the control sample was void of compost; hence the microbial activities were minimal. After 8 weeks of remediation, the RHC in each sample decreased quantitatively. This signifies that there was an improvement in the degree of remediation offered by the samples containing waste material (compost), over the control. It is also evident that the amount of amendment introduced affects the rate of bioremediation.

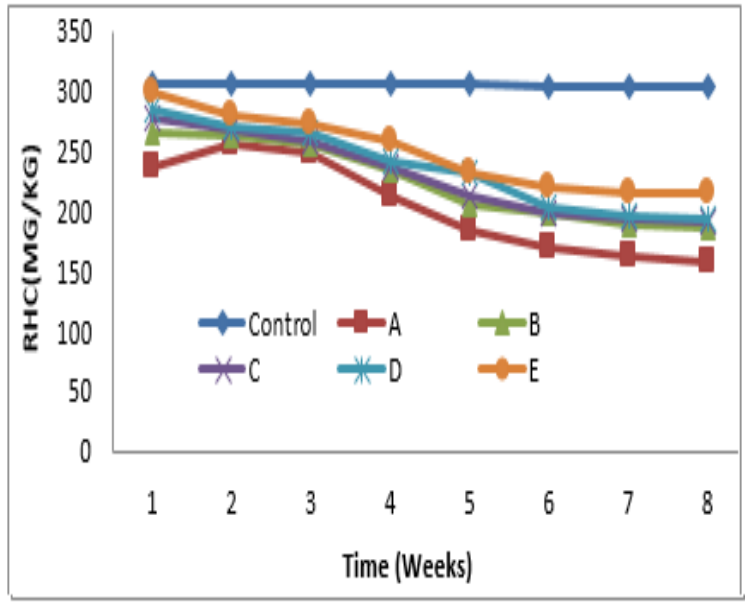

Fig 2: Variation of RHC with time

Total Microbial Count (TMC):Figure 3 shows the total microbial count (TMC) for 8 weeks. It was observed that there was an increase in microbial count between week 1 and 2 for each of the samples, excluding the control which experienced little or no change. There was a corresponding increase in week 3 , at this time the microbes had adapted to the toxic environment and began to multiply. It was also observed from the graph that there was a decrease in total microbial count in some of the samples in the fifth week. This may have been as a result of competition for food, space and nutrients amongst the microbes resulting in the death of some of microbes, hence a reduction in their population. Consequently, it can be said that microbial growth is dependent on the number of nutrients or food made available to the microbes which would affect the rate of biodegradation. Previous reports have it that a high number of certain oil-degrading microbes from the oil-polluted environment are evidence that these microbes are vigorous degraders of the pollutants in the environment (Okerentugba et al., 2003). Other reports associated the increase in proliferation to not only hydrocarbon degraders but additional populations that utilize the resultant products from hydrocarbon break-down (Atlas and Bartha, 1992; Okpokwasili et al., 1990).

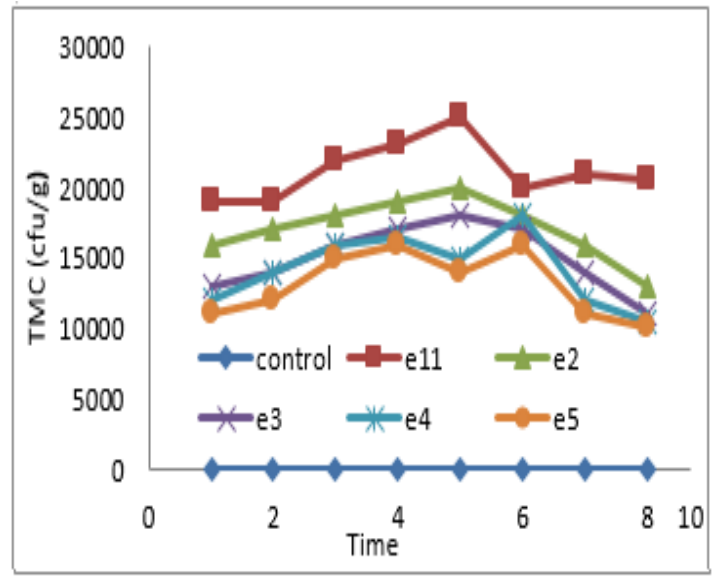

Fig 3: Variation of Total microbial count with time

Conclusion: This study was aimed at determining the efficiency of compost as a biostimulant in the remediation of crude oil contaminated soil. It can be concluded that an increase in the amount of biostimulant resulted in an increase in the total microbial count, which resulted in a proportionate increase in the remediation of crude oil-contaminated soil. It can also be concluded from this study that the amount of bio-stimulant applied in the remediation of crude oil contaminated soil does not have any significant effect on the $\mathrm{pH}$ of the soil during the process of remediation.

\section{REFERENCES}

Amenaghawon, NA; Asegame, PA; Obahiagbon, KO (2013). Potential application of urea and NPK 15: 15: 15 Fertilizers as biostimulants in the bioremediation of domestic wastewater. Am. J. Environ. Prot. 1(4): 91-95. 
Atlas, RM; Bartha, R (1992). Hydrocarbon biodegradation and oil spill bioremediation. Adv.Microb. Ecol. 12:287-338.

Bassiri, E (2011). Enumeration of Microorganisms using a counting chamber. J. Microbiol. 14(5): 5 10.

El-Fantroussi, S; Agathos, SN (2005). Is bioaugmentation a feasible strategy for pollutant removal and site remediation? J. Biol. Med. Environ. Sci. 8(3): 268-275.

Erdogan, EE; Karaca, A (2011). Bioremediation of crude oil polluted soils. Asian J.Biotechnol. 3(3): 206-213.

Golodyaev, GP; Kostenkov, NM; Oznobikhin, VI (2009). Bioremediation of oil contaminated soils by composting. Eurasian Soil Sci. 42: 926-935.

Obahiagbon, KO; Amenaghawon, NA; Agbonghae, EO (2014). Effect of initial $\mathrm{Ph}$ on the Bioremediation of crude oil polluted water using a consortium of microbes. Pacific J. Sci. Technol., $15: 452-457$
Okerentugba, PO; Ezeronye, OU (2003). Petroleum degrading potentials of single and mixed microbial cultures isolated from rivers and refinery effluents in Nigeria. Afr. J. Biotechnol.. 2(9): 288 - 292.

Okpokwasili, GC; Nwosu, AI (1990). Degradation of Aldrin by bacterial isolates. Niger.J. Technol.Res. 2(1): $1-6$.

Osuji, L; Nwoye, I (2007). An appraisal of the impact of petroleum hydrocarbons on soil fertility. Afr. $J$. Agric. Res. 2: 318 - 324.

Otokunefor, TV; Obiukwu, C (2010). Efficacy of inorganic nutrients in bioremediation of a refinery effluent.Scientia Africana, 9(1): 111 - 125.

Satsangee, R; Ghosh, P (1990). Anaerobic degradation of phenol using an acclimated mixed culture. Appl.Microb. Biotechnol. 34: 127-130.

Vidali, M (2001). Bioremediation: An overview.J. Appl. Chem. 73(7): 1163-1172. 